\title{
ECOLOGICAL INTELLIGENCE ON NOVEL SI ANAK PINTAR BY TERE LIYE
}

\author{
Sigit Arif Bowo \\ Institut Agama Islam Negeri Surakarta, Indonesia \\ Jalan Pandawa, Pucangan, Kartasura, Sukoharjo, Indonesia \\ Corresponding Author: sigit.arifbowo@gmail.com
}

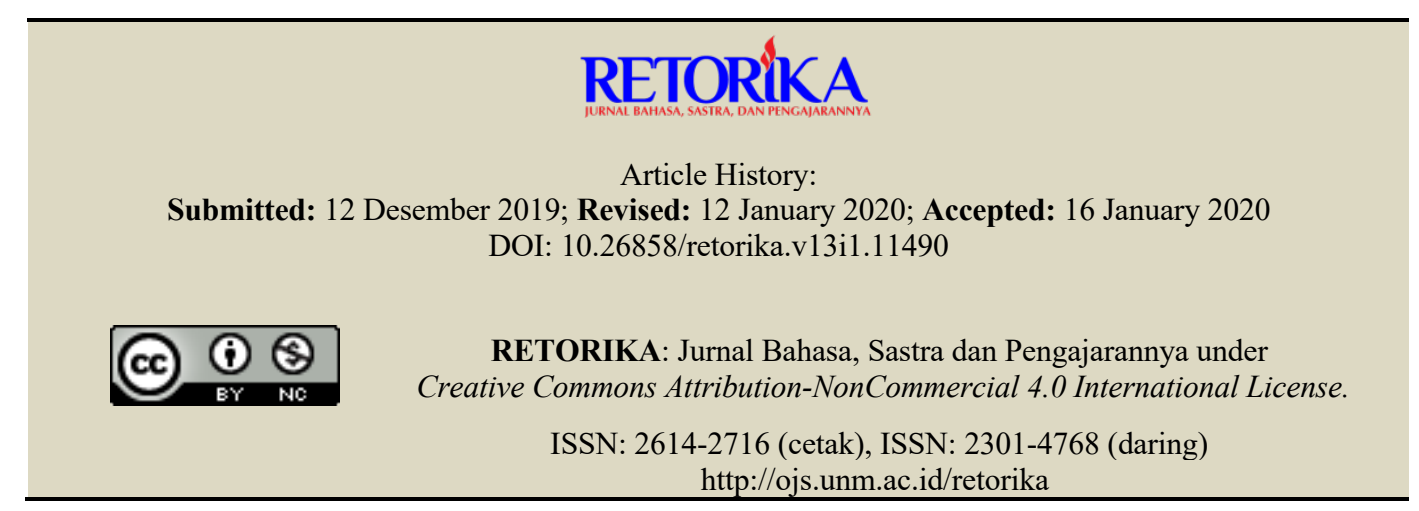

\begin{abstract}
This study aims to reveal the form of ecological intelligence in the novel Si Anak Pintar (SAP) by Tere Liye. This research is in the form of descriptive qualitative. Data collection techniques using the technique of reading and taking notes. Theory triangulation is used to validate data. Content analysis is used as an interactive analysis technique. The results of the analysis show that the forms of ecological intelligence contained in the SAP novel are (1) identifying ecosystem components; (2) understanding the function of ecosystem components; (3) understanding the natural and environmental management system; (4) understanding environmental values; (5) showing concern for environmental damage; (6) adapting the environment; (7) solving problems from environmental effects; (8) managing natural resources; and (9) using the environment positively.
\end{abstract}

Keywords: Ecological intelligence, novel, Si Anak Pintar

Forest fires that have affected many areas in Indonesia have attracted serious attention from various parties, including neighbouring countries. This haze affects not only local inhabitants but also Malaysia and Singapore. According to data from the National Disaster Management Agency (BNPB), more than 800 thousand hectares of land were burned during 2019. This figure is higher than the area of land burned in previous years. Nearly all of Indonesia's regions experience forest fires on both peatlands and mineral land with the most wide- spread distribution occurring in the Kalimantan and Sumatra islands (http://www.bnpb. go.id).

The effect of forest fires is a thick smoke haze that decreases driving visibility and reduces the air quality that results in a URI. Several regions reported a decrease in air quality by showing unhealthy levels. It resulted in the citizens should have to evacuate and treated with oxygen. Another effect is the reduction of forest area as the world's lungs. Destruction of the forest also causes some animals to lose their ecosystems so that they look for new lo- 
cations in residential areas. Nevertheless, there are not small economic losses.

BNPB data showed that $99 \%$ of forest fires are caused by humans, while the remainder is caused by natural factors. For forest fires, the human factor is conducted individually or in groups. Ordinarily to clear land. It is done because of their desires or paid by certain parties. About $80 \%$ of the land is used for plantations after forest fires. (http:/www. bnpb.go.id).

The greed of a few individuals is due to a lack of ecological awareness. According to Harsono (2008), ecology is defined as a study of the patterns of relationships between plants, animals and humans in their environment. Ecological awareness must be developed to reduce the impact of environmental damage to achieve sustainable living. Yuniarto (2013: 12) added that environmental awareness is a deep mental awareness that comes from knowledge and experience about the nature of the environment as a system that must be managed with full responsibility.

According to Kuo (2013:61), ecological awareness is related to local wisdom. The form can be seen in traditional customs, such as the request to hunt, heaven's thanks for the food, and so on. Turner et al. (2000) strengthened this belief by claiming that ecological knowledge is related to sustainable living practices and strategies, philosophies or worldviews, and the communication and exchange of knowledge and information.

Based on the explanation above, it can be concluded that ecological awareness is an awareness that is manifested in the form of attitudes, knowledge, and actions of responsibility for the existence of the environment. Ecological awareness is also associated with local wisdom as a source of life perspectives in order to preserve a sustainable environment.

In particular, such literary works pose environmental or ecological concerns. That is reasonable because literature is a form of social representation. Fannanie (2001) revealed that literary works seem associated with particular momentum in human history because more social events than art are taken from them. The social reality is, however, packaged as works added by fictional narratives.

Literary works have different advantages as a representation of life portraits. Not only as entertainment, but literature is also a useful educational media. The message contained is always relevant to time circumstances. AlMa'ruf and Nugraheni (2017:46) explained that various literary values enrich mental treasure which is not found elsewhere such as social, humanitarian, cultural, ambition, sympathy, tolerance can build motivation and character.

The Novel of Si Anak Pintar-after this abbreviated to $S A P$-by Tere Liye is one of the novels of the Indonesian family series. The novel is full of values which can be used as a representation of social phenomena. The novel includes elements that can be used as guidance for knowledge and environmental awareness.

Literary works which raise environmental issues are known as ecocriticism or literary ecology. Ecocriticism is the science which discusses literature's relationship to the physical environment, as stated by Glotfelty (1996: xviii). Garrard (2012:5) stated, in accordance with this opinion, that ecocritics is a research that explores relations between human beings and other components, including the history of human culture, which includes literary relationships with the environment. Ecocritics is unique among contemporary literary and cultural theories because of their close relationship with ecology.

Endraswara (2016:4-5) explains that literary ecology needs to reveal: (1) the application of ecological concepts into literature when the approach is made by making the earth (nature) the center of its study; (2) capturing literature as a text that reflects ecological conditions, such as dirty, clean, inundated, and so on; (3) studying certain environmental receptions on literary works; (4) capturing the role of the environment in creative literature.

Garrard (2012:6) explained that specifically, ecocritics studies could not contribute much to debates on ecological issues. This research will, however, help to define, analyze and offer solutions from a different perspective to ecological problems. One form of perspective offered by ecocritics in responding to environmental problems is through ecological intelligence. Suwandi et al. (2016) explained that ecological intelligence is the ability of humans to interact, adapt, regulate, maintain, preserve, and utilize the environment for human life as best as possible with full responsibility. Besides, Suwandi et al. (2017) said that there 
were nine aspects of ecological intelligence based on the results of his synthesis of theories proposed by various experts.

First, identify ecosystem components. Generally, the ecosystem is divided into two components: abiotic and biotic. The abiotic component consists of inanimate objects, while the biotic component consists of living things. Second, understand the function and usefulness of ecosystem components. Each component of the ecosystem, both abiotic and biotic, has functions and usefulness. Exploration activities will add insight into the functions and uses of previously unknown ecosystem components. Third, understand the natural and environmental management system. Good management will have a good environmental impact as well and vice versa. The effect that can be seen is environmental destruction that harms people and other living things.

Fourth, understand environmental values. Ecological intelligence cannot be separated from values. Nature always teaches the value of how to relate, manage and utilize its results. The values of local wisdom, religious values and moral values are very closely related to the community. Fifth, empathy for environmental damage. Not only related to knowledge and skills alone, ecological intelligence also involves aspects of attitude. Empathy values against damage to the environment and pollution must be shown. Sixth, adapt the behaviour to the environment. Each region has unique characteristics. Even in the effort to process and utilize nature needs adaptation. It is intended that the processing activities can work efficiently and effectively. In addition, there are no adverse and harmful effects on the environment.

Seventh, find solutions to environmental impacts. Environmental damage is unacceptable. In order to mitigate the damage, an initiative which is followed by concrete steps is needed. Eighth, manage natural resources. As time passes, the use of natural resources can not be avoided. Management activities must, however, pay attention to all aspects, including the ecosystem within them. Nine, use the environment positively. It needs proper studies and policies to make use of the environment. Full efficiency is desired without disturbing the balance of the current ecosystem.
Based on the opinions of these experts, it can be defined that ecological intelligence is the ability of humans to interact and manage the environment as well as sustainable life as possible. Furthermore, the form of ecological intelligence that will be used as an analytical tool is a form of ecological intelligence delivered by Suwandi et al.

Some researchers explore the ecological forms in literary works such as Prasetya and Nurhadi (2019) through the results of their research entitled Spiritual Ecology in Novels of Glonggong written by Junaedi Setiyono and Jatisaba written by Ramayda Akmal. The study described the Javanese ecology in the Glonggong and Jatisaba novels. There are two ways of representing the environment's mutual relationship with humans: (1) humans live in harmony with nature and (2) man regulate nature. Of the two forms of relationship in the two novels, there are a Java-nese spirituality that influences environmental management, including saduluran (kinship), bisa ajur ajer (able to adapt and select), and nrima ing pandhum (accepting all gifts or sincerity).

Another study conducted by Lusyantie et al. (2019) entitled Environment and Habitus in Kalimantan Folklore and Papuan Folk Stories Ecocritical Study. The research focused on ethical studies of (1) respect for nature, (2) attitude of responsibility towards nature, (3) attitude of solidarity with nature, (4) attitude of compassion and care for nature and (5) attitude of non-intrusion towards nature shown in literary works. Through this research, several findings were obtained regarding the pollution of the aquatic environment, habitat destruction, and management of nature or the environment.

Based on the explanation of relevant theories and research that have been submitted, this research will discuss about the form of ecological intelligence in the novel Si Anak Pintar by Liye (2019).

\section{METHOD}

This type of research is descriptive qualitative. The data source of this research is Tere Liye's novel Si Anak Pintar, published in 2019 with 349 pages. The data in this study are in the form of words, phrases and sentences contained in the novel Si Anak Pintar by Tere Liye 
related to ecological intelligence. Data collection techniques using reading and writing techniques. Theory triangulation is used to validate data. While interactive analysis is used to analyze the problems studied. The analysis steps is done by (a) data collection, carried out by collecting library materials and repeatedly reading in the novel Si Anak Pintar, (b) data reduction, carried out by recording, classifying data and discarding data that is not following the research problem, (c) the presentation of data is done by presenting data based on the results of research and formulation of the problem, and (d) drawing conclusions.

\section{FINDINGS AND DISCUSSION}

\section{Findings}

Based on the results of the analysis, there are nine forms of ecological intelligence in the novel Si Anak Pintar by Tere Liye, which are described as follows. (1) identifying ecosystem components; (2) understanding the function of ecosystem components; (3) understanding the natural and environmental management system; (4) understanding environmental values; (5) showing concern for environmental damage; (6) adapting the environment; (7) solving problems from environmental effects; (8) managing natural resources; and (9) using the environment positively. The data presentation from the results of the analysis is shown in the Table 1.

\section{Identifying Ecosystem Components}

The ecosystem component is an important part of an environment. Its presence is not only a part of the ecosystem. Moreover, these components are involved in the cycle system. Each ecosystem has similarities and different components. Some of these components have a relationship (symbiosis) and some are not. Examples of ecosystem components included in quotation of the novel SAP are as follows.

Today we are allowed again to help clear the land. It's fun listening to the noise of birds, lenguh simpai (a kind of yellowhaired monkey), and the rattling of insects along the way. (SAP, pages 288))
Based on the above quotation, it can be seen that in the forest ecosystem, there are biotic components in the form of birds, lenguh simpai, and insects. Components such as birds and insects can be found in other ecosystems. For example, in the ecosystem of rice fields and fields. The interesting thing is the existence of lenguh simpai. Lenguh simpai is the designation of local residents for a type of yellow-haired monkey. If we observe, maybe the existence of these animals is only in the forest in certain areas. It may be that the same type will be found in other regions with different names and different species. Extensive insight is needed in the identification of ecosystem components for further uses such as mapping the types and locations of animals as a form of preservation of flora and fauna.

Table 1. Results of Ecological Intelligence Types Found in Novel of $S A P$

\begin{tabular}{clc}
\hline Number & $\begin{array}{c}\text { Ecological Intelligence } \\
\text { types }\end{array}$ & Amount \\
\hline 1. & $\begin{array}{l}\text { Identifying ecosystem } \\
\text { components }\end{array}$ & 14 \\
2. & $\begin{array}{l}\text { Understanding the func- } \\
\text { tion of ecosystem compo- } \\
\text { nents }\end{array}$ & 6 \\
& $\begin{array}{l}\text { Understanding the natural } \\
\text { and environmental man- }\end{array}$ & 14 \\
3. & $\begin{array}{l}\text { agement system } \\
\text { Understanding environ- } \\
\text { mental values }\end{array}$ & 13 \\
4. & $\begin{array}{l}\text { Showing concern for en- } \\
\text { vironmental damage }\end{array}$ & 1 \\
6. & $\begin{array}{l}\text { Adapting the environment } \\
\text { Solving problems from } \\
\text { environmental effects }\end{array}$ & 3 \\
7. & $\begin{array}{l}\text { Managing natural re- } \\
\text { sources }\end{array}$ & 4 \\
8. $\begin{array}{l}\text { Using the environment } \\
\text { positively }\end{array}$ & 3 \\
\hline
\end{tabular}

\section{Understanding the Function of Ecosystem Components}

By nature, God has provided for all pleasures. With all the advantages and benefits, including plants, diverse abiotic and biotic components are produced. Various plants are created with various functions. From the roots to the leaves, the benefits can be taken. Some are made into wood, food wrappers, even food. However, there are plants that remove water 
from the roots that can be drunk. It takes great knowledge and extensive experience to know this because not everything can be drunk. That is just as Bakwo Dar did in the quotation below.

Bakwo Dar also showed his extensive knowledge of natural affection. When finding a tree root that hung down from a giant tree, Bakwo Dar called out to us. Bakwo Dar pointed to the roots. "Are you thirsty?" We nodded. Bakwo Dar pulled one of the roots closer. Splash! Cut it once cut. and ... Oh! Clearwater flows swiftly from the root fragments. Bakwo Dar expressively drank it, and we, of course, scrambled to be given a turn. (SAP, pages 281)

Based on the quote above, it seems the vast expertise and experience of Bakwo Dar. He can identify and understand the function of certain trees whose roots can release water to drink. Indeed, the information is not gained by entering the forest once or twice. There are, of course, many more advantages from other parts of the plant which have not been identified for their use. Many mysteries about the benefits of plants that have not been solved. For example, discovered the benefits of plant roots that can treat cancer. That opens up the horizon space as well as challenges in the field of research to explore the benefits of other plants.

\section{Understanding the Natural and Environ- mental Management System}

Nature and environment management demands knowledge and insight. It is intended to allow the process performed to proceed well. Additionally, the negative impacts can be minimized or will produce a positive impact. The same thing happened during clearing and burning down the forest. Clear knowledge of the management system is needed to maximize its effectiveness and reduce risks to the maximum possible degree. Management can be interpreted as planning, implementation and evaluation of the post-activity activities. Planning starts from cleaning the bush, cutting trees, and making the separation. Implementation begins with dry bushes and trees burning up until they are entirely burned while the post-activity evaluation is performed by ensuring the results of perfect combustion. The form of understanding of the environmental management system is carried out by father, as indicated in the following quotation.

\begin{abstract}
How crossing the trees that are felled evenly across the entire plot of land, not only piling up on one side but less on the other, is the key to the success of the burning phase. Wrongly arranged, the land will be pockmarked, some parts are too fertile, some are otherwise. That is why father told me not to cut down tree trunks immediately, and there is a formu-la. (SAP, pages 290).
\end{abstract}

Based on the above quote, it turns out that the production of land for planting has a management system that is not easy. Land can be fertile to be planted when it has sufficient nutrients. Those nutrients are obtained through perfect combustion results. Combustion can work well if the leaves and trees have entirely dried up and evenly covered the soil. The exciting thing about the quote is "sudah ada rumusnya". Simply passing through the clearing of land to combustion requires a formula. The formula, of course, does not come from speculation, but from many experiments or experience. Understanding the management steps will have an impact on working efficiency as well as time, energy and cost-efficiency. In addition, the conservation of nature and the environment is maintained.

\section{Understanding Environmental Values}

The process of planting seeds into rice requires a long process. In contrast to modern agriculture, which sometimes ignores values, traditional agriculture still retains values. These values are demonstrated in both religious and social ways. It can be seen from the following quote.

\section{Ooi, planting a grain grows into seven \\ Seven stems bloom seven stems \\ Seven stems bear seven fruits \\ Multiply the goodness of nature's rulers}

Wak Yati began the procession of stock-ing seeds. Her raspy voice eloquently chanted, to the ends of the land.. (SAP, pages 310)

The quotation above is a form of religious value that is still being used when planting. The song is offered to The ruler of nature as a hope for the good of agricultural products. Land, fields, forests are part of nature created 
by God. Farming activities cannot be separated from religious aspects. Farming is more than just for biological needs; it is a form of synergy with nature.

Agricultural activities cannot be separated from religious values. Such a pattern can be found in Java agriculture as well. Several processions have been carried out as part of agriculture. For example, the existence of alms made with the hope that the harvest could be abundant. More-over, post-harvest residents also make the same thing as an expression of gratitude for the crops given and the hope that there will be abundant yields from subsequent planting activities.

Furthermore, traditional farming is still full of social values. This value is realized in the form of gathering together when there is a celebration or thanksgiving from one of the community members. That is commonly done in partnership with one another. Land clearing and seeding activities are carried out by involving the surrounding community. It can be seen from the following quotation.

After nearly three months of preparation, starting from saving shrubs, cutting down tree trunks, making dividing lines, then burning, the fields are ready for use. Today is the day to sow seeds. Mamak only invited all the villagers, as well as thanksgiving. (SAP, pages 305)

Social values and mutual cooperation still exist in the rural environment. Preparations to clear the land for months and spread the seeds are done together. There is a collective agreement to this value. The owner of the land should feel happy with mutual assistance programs; the activities carried out can work and can minimize expenses to pay for labour costs. In the meantime, other residents also feel happy to be able to support others and with the expectation that other residents will also assist if they have a need.

\section{Showing Concern for Environmental Dam- age}

Empathy is an important form of personality to have. Concern for environmental damage must be built into a person. The environmentcare attitude is formed through empathy. It is as in the quote below.
We understand, once the forest perishes, our lives also perish. Do the forest destroyers from the city have that understanding? This is the difference between them and us. (SAP, pages 296-297).

Based on the quote, the attitude of empathy or concern for environmental damage is embedded in the citizens. This attitude is a source of knowledge and action. Knowledge gained is the awareness that life will also perish if forests perish. Forest fire perpetrators should pay attention to this value because the temporary benefits that aren't comparable to the impact of the losses that have occurred. The destruction of the forest has produced a large domino effect.

All parties, especially those directly involved (the perpetrators), should own concern for natural damage and environmental pollution. Government efforts to overcome the nature destruction will be in vain if the perpetrators do not have the awareness and empathy. Empathy must be maintained by all parties, both individuals and corporate groups, in addition to clear and firm regulations.

\section{Adapting the Environment}

The environment is constantly changing due to various factors. The changes are occurring faster than predicted. The method that is usually used sometimes has to be adapted to new circumstances. Quick adaptation is necessary to keep track of the changes that occur, even in agricultural activities. Changes occurring in land, plants, and the environment require a quick response. It can be seen from the quotation below.

When the rice straw is getting higher, you invite us to put cans filled with coral in every corner of the field ... like a spider's web, all the cans are connected to the loom with a raffia rope. (SAP, pages 313)

Based on the above quotation, Bapak has the ability to adapt the environment well. When the rice stem is higher, it means that the stem begins to contain rice seeds. That will undoubtedly have consequences in the form of nuisance animals such as birds and pigs moving in. Adaptation is accomplished by placing 
stonefilled cans bound with raffia. Another way is to make a fence like the quote below.

Father also made fences around the fields, using hundreds of small pieces of wood. This tight fence is essential to prevent wild animals from entering and damaging rice stalks. (SAP, pages 312).

Those behavior is a response to anticipate the negative effects of crop failure due to being eaten by animals. If we observe that Bapak's or the farmers' response seems simple. With this simple technology, however, it has proven to be effective and efficient in solving pestcausing problems. It challenges developers of agricultural technology to create inventions in agriculture and others that lead to natural changes or developments in agriculture.

\section{Solving Problems from Environmental Ef- fects}

Forest fires are disasters that occur as a result of natural and human factors. Human factors can be divided into accidental or intentional. The desire to clear land easily and cheaply makes individuals or corporations unconcerned. However, those did not happen to Bapak and other residents. Bapak is very thorough and carefully calculates the situation before burning, especially for peatlands that are flammable. It is in accordance with the following quote.

"You do not want the whole forest to go up in flames, do you?" Dad relaxed, asking when Burlian asked why we had to do it. So, without asking again, we began to draw a dividing line. With an area of one hectare, that means that nearly four hundred meters of the dividing line take two weeks. (SAP, pages 295.)

Sometimes forest fires occur due to human accidental factors. Land that is not burned gets burned because of the influence of natural factors like wind. We, therefore, need a solution to these problems. Based on the quote, the solution to avoid forest fires when burning land is to make a separator. The separator is made to ensure that the fire does not spread to other lands. It requires a lot of effort and time in mathematical terms. Such efforts, however, are a form of environmental love and efforts to prevent unwanted impacts.

\section{Managing Natural Resources}

Natural resources become a source of support for human life. Its existence is the driving force of human life. Good management will maintain its sustainability and usefulness. One effort to make the management last a long time is to preserve it. Natural resource conservation is done through the implementation of a system of natural cycles, that is, reopening old fields. As explained in the quotation below.

It is a mistake if there is a rate of villagers who have contributed to the most significant portion of forest destruction. In fact, from decades ago until now, the area of land planted by villagers was just that. Not every year they burn the forest. More like a natural cycle, it is just reopening old fields that have not been taken care of for years. (SAP, pages 279)

Based on the above quotation, it can be seen that the villagers individually and collectively protect nature. The management system is applied by implementing a natural cycle method by clearing the once used land. When its use is limited, it will apply opening up new land. If the land is less productive, then the old cleared land is recycled, and so on. Implementing such a system will still maintain the natural balance. The amount of land cultivated and not touched will remain the same.

\section{Using the Environment Positively}

The environment must be used and managed positively. One form is to make planning and priority scale. Cutting trees that are part of the future land is among the stages of activity in clearing land. Not all trees should be cut off from the activity. Productive and useful plants and trees must be considered. Bapak and residents' activity in clearing land observe this aspect. It is shown in the following quote.

Except for the five trees that were deliberately left behind, all the trees in that piece of the forest had been cut down. Five remaining three of them durian tree and two mangosteen trees. (SAP, pages 295) 
Durian and mangos teen trees are seasonal fruit trees whose benefits and delicious fruits are very well known. Forest cutting or land clearing activities should pay attention to usefulness aspects. Plants and trees that have benefits must be preserved. Land clearing does not mean cutting or burning down plants without seeing positive aspects. Additionally, other aspects, such as the presence or absence of threatened plant or animal species, should be taken into account when determining the location of the land. Do not expect advantages but sacrifice a lot.

\section{Discussion}

Based on the results of the analysis, there are nine forms of ecological intelligence in the novel Si Anak Pintar by Tere Liye. Ecocritical studies aim to persuade people to rethink the relationship that humans should have with the environment because global conditions are increasingly competitive with modern lifestyles that affect the environment. Winarno (2017) said that globalisation, which overexploited natural resources, triggered economic competition. These activities resulted in a global environmental crisis.

Ecocritical analysis of literary works reveals problems and solutions to environmental issues. Jahan \& Islam (2016) revealed an ecocritical study of the novel An Enemy of the People. Critical studies of cultural texts not only contribute to the emergence of ecological awareness but also to the policy of developing natural construction. A similar form was also conveyed by Uniawati (2014), who discussed the symbiotic relationship between humans and the sea and the romanticism of men in women and nature. There are three categories of human relations with nature; (1) nature must be feared; (2) nature must be conquered, (3) maintain the harmony of nature.

Another example was given by Juanda (2018), who conveyed the phenomenon of environmental exploitation in the short story of newspaper. The study results showed that there are six environmental phenomena that consist of pollution (water pollution), wilderness (forest destruction), natural disasters (landslides), animal settlements, and earth.

However, the results of existing research are still under discussion on the analysis of ecocritical elements and have not examined ecological intelligence. Ecological intelligence is a form of a solution that can be used to overcome environmental problems. As stated by Garrard (2012:6) that an ecocritics study provides solutions to environmental problems from a different perspective.

It is important to master the ability to identify ecosystem components and their functions. Biodiversity and natural resources are an irreplaceable part of the ecosystem. Its existence is bound together by a symbiosis. For example, the existence of fauna in the forest as their habitat. If the forest is reduced or depleted, the survival of the fauna is likely to be threatened. Understanding the components and functions of an ecosystem will make people know how important the existence of these components.

Keeping ecosystem components continuous requires an understanding of natural management systems. The desire to explore the existence of Natural Resources will end with irresponsible exploitation if not followed up by a good management system. That is why it takes an understanding of environmental values. Local wisdom values which have protected nature need to be preserved. If that is done, a responsible attitude will develop in natural resource utilization.

It is also necessary to develop attitudes towards environmental damage in addition to understanding the components of the ecosystems and the values. This attitude can be realized by showing concern for environmental damage. Pollution and environmental damage is an inevitable phenomenon. Through empathy, somebody will have the knowledge and behaviour needed to make progress. These actions can take the form of environmental adaptation, solving problems from environmental impacts, managing natural resources, and using the environment positively.

The results of this study can be used as a reference in the literature of learning at both primary and secondary and university levels. It is in line with Bowers (2011) opinion that a rethink of ecological intelligence's contribution to education is needed. There are at least three connections that need attention. First, formulate the attributes of ecological intelligence so that each individual understands their characteristics. Second, a broad teacher understand- 
ing for internalizing early understanding of environmental limitations. Third, about how to revitalize culture, how ecological awareness enters learning activities.

If we look closely, the nine types of ecological intelligence have been internalized in the form of aspects of learning which include knowledge, attitudes, and skills. Knowledge as-pects are reflected in the forms of ecological intelligence number one to four. The value of attitude is reflected in ecological intelligence number five. While ecological intelligence number six to nine forms the value of skills.

Internalization of ecological intelligence through literary works is possible in learning activities. Literary work as a social reflection plays a role in the development of culture and national character. Curriculum Research and Development Agency (2010:7) reinforces that education based on culture and character functions as the development of the potential of students to become well-behaved and dignified individuals. Furthermore, these activities are also a means of cultural screening.

Ecological intelligence in the SAP novel is very appropriate to be used as an alternative solution to internalize student characters. Mainaki et al. (2018) reported that the degree of ecological intelligence differs among high school students in Cimahi. Based on the ecological intelligence component, the attitude aspect has the highest score, followed by

\section{REFERENCES}

Al-Ma'ruf, A.M. \& Nugraheni, F. (2017). Pengkajian sastra: Teori dan aplikasi. Surakarta: Djiwa Amarta Press.

Badan Penelitian dan Pengembangan Kurikulum. (2010). Bahan pelatihan penguatan metodologi pembelajaran berdasarkan nilai-nilai budaya untuk membentuk daya saing dan karakter bangsa: Pengembangan pendidikan budaya dan karakter bangsa. Jakarta: Kementerian Pendidikan Nasional.

Bowers, C. A. (2011). The challenge facing educational reformers: Making the transition from individual to ecological intelligence in an era of global warning. The International Journal of Illich Studies, 2(1), 13-20.

Endraswara, S. (2016). Metodologi penelitian ekologi sastra: Konsep, langkah, dan penerapan. Jakarta:Buku Seru. knowledge, skills, and participation. Efforts to increase ecological intelligence through school and learning programs need to be supported by all parties. Through learning, this form of ecological intelligence can be developed in teaching materials such as reading and evaluation.

\section{CONCLUSION}

Ecological intelligence is something that everyone must have. Based on the results of the analysis, there are nine forms of ecological intelligence in the novel Si Anak Pintar by Tere Liye, including: (1) identifying ecosystem components; (2) understanding the function of ecosystem components; (3) understanding the natural and environmental management system; (4) understanding environmental values; (5) showing concern for environmental damage; (6) adapting the environment; (7) solving problems from environmental effects; (8) managing natural resources; and (9) using the environment positively. Those forms should be owned by everyone in response to fires and natural damage which are increasingly unavoidable. Ecological intelligence is used as a guideline for maintaining, managing, and using nature as well as possible and with full responsibility. Besides, ecological intelligence can be internalized through literary learning as teaching material.

Fananie, Z. (2001). Telaah sastra. Surakarta: Muhammadiyah University Press.

Garrard, G. (2012). Ecocritcism. New York: Routledge.

Glotfelty, C. (1996). Introduction: Literary studies in an age of environmental crisis. In Glotfelty, Cheryll and Fromm, Harold (Eds.), The Ecocriticism Reader: Landmarks in Literary Ecology Georgia: University of Georgia Press.

Harsono, S. (2008). Kritik sastra berwawasan lingkungan. Kajian Sastra, 32(1): 31-50.

Jahan, Md. S. \& Islam, S. S. (2016). Ecocritical and eco-social reading of ibsen's an enemy of the people. IOSR Journal Of Humanities And Social Science (IOSR-JHSS). 21(2): 52-56, www.iosrjournals.org. http://doi.org/10.9790/ 0837-21245256 
Juanda. (2018). Fenomena eksploitasi lingkungan dalam cerpen koran minggu Indonesia pendekatan ekokritik. AKSIS Jurnal Pendiidkan Bahasa dan Sastra Indonesia, 2(2): 165189. http://doi.org./10.21009/ AKSIS.

Kuo, S. (2013). Climate change and the ecological intelligence of confucius. Journal of Global Ethics, 7(2): 57-66.

Liye, T. (2019). Si anak pintar. Jakarta: Republika Penerbit.

Lustyantie, N., Setyowati, N., \& Rohman, S. (2019). Environment and habitus in Kalimantan folklore and Papuan folk stories ecocritical study. Paper Presented in International Conference on Literature: Literature as a Source of Wisdom, July 11-13, 2019, Universitas Syiah Kuala, Banda Aceh, Indonesia.

Mainaki, R., Kastolani, W. \& Setiwan I. (2018). Ecological Intelligence Level of Hight School Students in Cimahi City. SHS Web of Conference,

42 , http://doi.org/10.1051/shsconf/20184200062.

Prasetya, Y. A. \& Nurhadi. (2019). Ekologi spiritual dalam novel Glonggong karya Junaedi Setiyono dan Jatisaba karya Ramayda Akmal. Indonesian Language Education and Literature, 4(2): 201-215
Suwandi, S., Yunus, A., \& Rahmawati, L.E. (2016). Kecerdasan ekologis dalam buku sekolah elektronik mata pelajaran bahasa Indonesia SMP. Litera, 15(1): 23-37.

Suwandi, S., Yunus, A., \& Rahmawati, L.E. (2017). Ecological Intelligence values in Indonesian language textbooks for junior high school students. Pertanika Journals Social Sciences \& Humanities. 25 (S): 237-248, http://www.pertanika.upm.edu.my/

Turner, N. J., Marianne Boelscher Ignace, Ronald Ignace. (2000). Traditional ecological knowledg and wisdom of aboriginal peoples in British Columbia. Ecological Applications, 10(5): 1275-1287, http://www.jstor. org/stable/ 2641283

Uniawati. (2014). Nelayan di lautan utara: Sebuah kajian ekokritik. Kandai, 10 (2): 246-257, https://doi.org/10.26499/ jk.v10i2.328.

Winarno, B. (2017). The value of international regime and global environmental crisis. Jurnal Hubungan Internasional, 6(1), 81-98, http:// doi.org.10.18196/hi.61107.

Yuniarto, B. (2013). Membangun kesadaran warga negara dalam pelestarian lingkungan. Yogyakarta: Deepublish. 